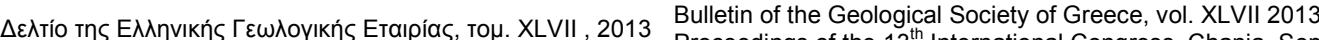
Xroceedings of the $13^{\text {th }}$ International Congress, Chania, Sept.

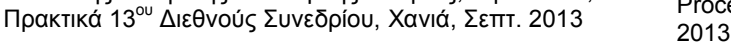

\title{
MOLLUSCAN ASSEMBLAGES IN A HIGHLY VARIABLE SETTING IN LITTORAL BOTTOMS OF THE LOWER PLEISTOCENE OF RHODES (GREECE)
}

\author{
Koskeridou E. ${ }^{1}$, Thivaiou D. ${ }^{1}$ and Giamali Ch. ${ }^{1}$ \\ ${ }^{1}$ National and Kapodistrian University of Athens, Faculty of Geology and Geoenvironment, \\ Department of Hist.Geology - Paleontology,ekosker@geol.uoa.gr,dthivaiou@geol.uoa.gr, \\ gchristi@geol.uoa.gr
}

\begin{abstract}
Highly diverse and well preserved marine mollusc associations from a sandy horizon of the Lower Pleistocene shallow water deposits of Rhodes island are here presented. Four significantly different molluscan assemblages characterize neighboring environments and document a variety of niches provided by the lateral change of bottom type. Molluscs of hard substrate to sandy seabed of the Infralittoral Zone were documented. A total of 55 molluscan species were identified. Gastropods dominate with 29 species. For the first time, the Ervilia castanea assemblage is described for the Lower Pleistocene of Greece.
\end{abstract}

Keywords: Molluscs, Lower Pleistocene, Rhodes, Greece.

\section{Пврі́र $\eta \psi \eta$}

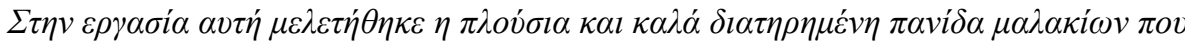

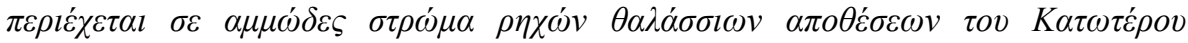

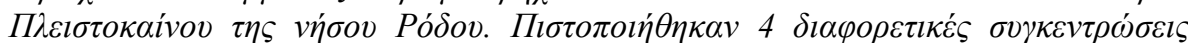

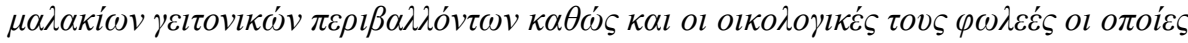

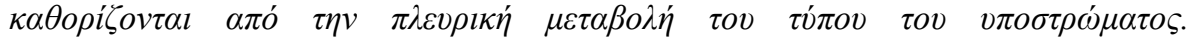

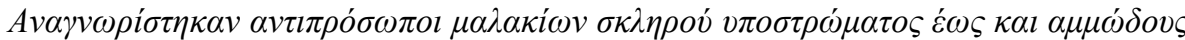

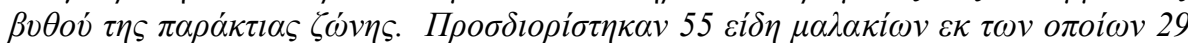

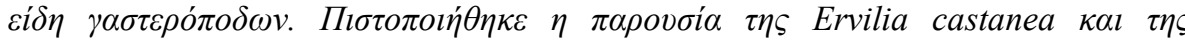

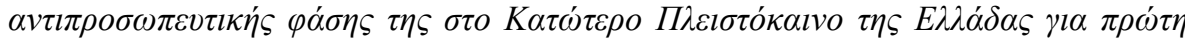

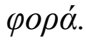

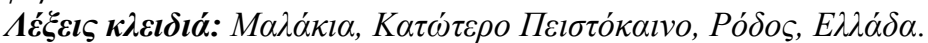

\section{Introduction}

Rocky bottoms often neighbor soft-bottom sandy areas in the sea. These two habitat types support very different communities of plants and animals. Fossil organisms of high-energy shallow water marine environments characterized by siliciclastic sedimentation are usually uncommon because of the transportation by bottom currents, the fragmentation and dissolution of their skeletons. On the contrary, fossil shallow marine hard bottoms provide an exception as they constitute stable substrates where rich fauna is developed. A good example of this are the Gelasian drowned beachrock beds of northeastern part of Rhodes island which have been studied by Moissette et al. 
(2013). These beds served as a zone of carbonate production and accumulation within a siliciclastic-dominated otherwise poor populated environment.

The Ervilia castanea (Montagu, 1803) facies characterizes wave exposed beaches from the Atlantic and the Mediterranean Sea has been studied and/or referred to by many authors (e.g. Morton et al. 1998, Zenetos et al. 2005). This facies is also one of the most representative siliciclastic facies in the deposits of Kritika member of Rhodes island.

In this study, highly diverse and well preserved marine mollusc associations accumulated in these deposits of the Lower Pleistocene have been recovered.

The main objectives of this paper are to compare the results obtained from the molluscs of the sandy bed from the Lower Pleistocene of Rhodes with those reported from the present-day Mediterranean and use this information to reconstruct the paleoenvironment and depositional conditions

\section{Geology}

The island of Rhodes is located at the easternmost part of the Hellenic sedimentary fore-arc, which resulted from the Cenozoic subduction of the African Plate under the Aegean-Anatolian Block (Fig.1).The Pliocene-Pleistocene sediments encountered at the northeastern part of the island provide basinal to littoral fossiliferous deposits that are well exposed in steep palaeovalleys cutting through the Hellenic Mesozoic basement (Meulenkamp et al. 1972, Pirazzoli et al. 1989, Hanken et al. 1996). This basement is mainly carbonated calcareous and it was faulted in different directions. Thus occur the numerous steep horsts and grabens that later defined the deposits of this age as far as their nature and geographical distribution is concerned (Mutti et al. 1970). The embayments of the Lower Pleistocene (Gelacian) formed the depositional environment of the Kritika Member of Rhodes Formation (Cornée et al., 2006). This age is given according to the recent redefinition of the Pleistocene (now inclunding the Gelasian Stage/Age as its lowermost unit, (Gibbard \& Head, 2010)). It is composed of pebbles, gravels, sands and clays of estuarine to marine terrigenous origin. These beds are fossiliferous thus preserving a diverse range of taxa that correspond to fossil assemblages belonging to precise environments (paralic, nearshore).

The present study focuses on sandy beds of one outcrop of the Kritika Member (Rhodes Formation) which is composed predominantly of siliciclastic deposits intercalated with hard bottom levels formed by the drowning of former beachrock beds (Cornée et al., 2006; Moissette et al., 2013).

\section{Materials and Methods}

Molluscan faunas were examined in one representative sample recovered from the studied succession (Fig. 1). The field observations included considerations of shell orientation, disarticulation, fragmentation and encrustations to distinguish whether or not the shells had been transported before final deposition. The benthic fauna was separated from the terrigenous fraction using a $0.5 \mathrm{~mm}$ sieve for molluscs and a $0.062 \mathrm{~mm}$ sieve for foraminifera. The molluscs, encountered within the $>0.5 \mu \mathrm{m}$ size fraction were classified to species level, using the descriptions based on numerous works by molluscan researchers. Then, they were semi qualitatively analyzed and an estimation of the number of specimens of each species was made.

Palaeoecological and palaeoenvironmental interpretation of species was based on a series of researches on modern analogue communities especially from the Mediterranean.

\section{Results}

The sediments have been assigned to shallow marine sandy shell bed where the shell debris accumulated due to wave action and storm events. 

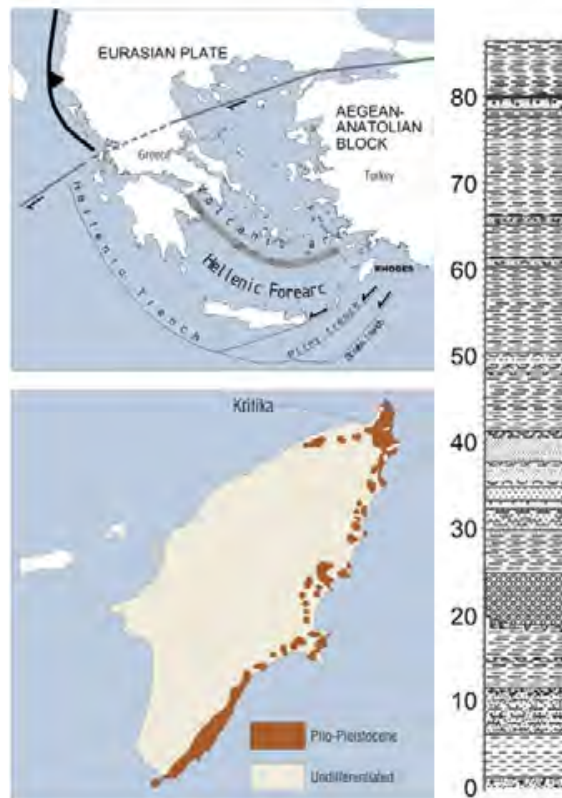

40

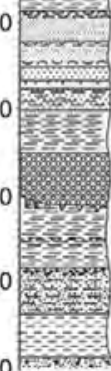

Ervilia Facies

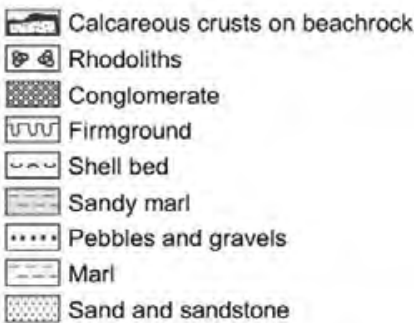

Figure 1 - Geographical location of the Island of Rhodes, location and lithological column of the Kritika Member section, Rhodes Formation.

The bivalves are represented by 26 species. The most abundant is the burrowing bivalve Ervilia castanea which is highly numerical dominated and is recorded for the first time in the Lower Pleistocene of Greece. The next most dominant species is the transported Anomia ephippium.

The benthic gastropod assemblage of 29 species is dominated by small climbing herbivorous forms, most of them grazing on epiphytes.

Many epibyssate forms have been identified: Talochlamys multastriata, Lima inflata, Mytilus galloprovincialis and Mytilaster lineatus, Acar clathrata, Barbatia barbata, Arca noae, Arca tetragona.

Nestling species as Cardita calyculata and Striarca lacteal also occur.

The infaunal elements that have been recognized are: Tellina distorta, Tellina donacina, Callista chione, Lucinella divaricata, Dosinia exoleta, Dosinia lupinus, Diplodonta rotundata, Cardites antiquatus, Acanthocardia tuberculata, Donacilla cornea, Callista chione, Venus verrucosa, Timoclea ovata, Euspira catena, Natica sp., Neverita josephinia.

The encrusting forms are: Anomia ephippium, Chama gryphoides, Vermetus sp., Dedropoma sp.

The crawling herbivores are: Haliotis tuberculata, Bolma rugosa, Jujubinus striatus, Jujubinus exasperates, Gibbula magus, Gibbula ardens, Clelandella miliaris, Danilia tinei, Alvania cancellata, Alvania lineata, Rissoa sp., Tricolia pullus, Bittium reticulatum, Bittium latreillei.

The carnivores Naticarius stercusmuscarum, Nassarius spp., Euspira catena, Natica sp., Neverita josephinia, Ringicula ventricosa, Diodora graeca, Diodora gibberula, Buccinulum corneum, Bolinus brandaris, have been also recovered.

The less dominant species are Ringicula sp., Nassarius sp., Callista chione, Mytilaster lineatus and Naticidae and rare species (1 specimen/species) are Striarca lactea, Acar clathrata, Mytilus galloprovincialis, Acanthocardia tuberculata, Lucinella divaricata, Lucinella divaricata, Talochlamys multistriata, Tellina distorta, Danilia tinei, Bolinus brandaris.

Except for the vermetids, all the other gastropods are well preserved. Among the bivalves the only articulated is Ervilia castanea while the while the remaining species are preserved unarticulated or fragmented. 


\section{Discussion - Conclusions}

Most of the taxa collected in this work, exist in the present Mediterranean Sea (e.g. Pérès \& Molinier, 1957, Pérès \& Picard, 1964, Pérès, 1967, Logan, 1979, Zibrowius, 1980, Riedl, 1983, Barash \& Danin, 1988, 1992; Zenetos et al. 2005), which enables a comparison between the palaeofauna and recent assemblages.

The studied malacofauna is the result of heterogeneous mixing of shells with different rates of abrasion, fragmentation and disarticulation, belonging to species typical of normal marine conditions and rocky, sandy or algal substrates from the littoral marine environments. Two different types of concentrations can be defined:

Autochthonous concentrations of bivalves found articulated in sandy substrates and parautochthonous concentrations of gastropods and bivalves, including some mixed allochthonous elements represented by abraded and fragmented shells of relatively deeper sublittoral species. These concentrations can be interpreted as the result of accumulation during storm events.

Four assemblages are found living on different substrates:

1. A vermetid assemblage. The upper mediolittoral zone biota of exposed rocky substrates is represented by Dedropoma and Vermetus fragments.

2. Ervilia castanea assemblage. Coarse sand habitat occurs in sand-wave formations in shallow water where the infauna is characterized by the small bivalve Ervilia castanea (Morton et al. 1998). The dense populations of this species in the studied material indicate that it is a very successful coloniser of such energetic environment. A comparison between the fossils from the studied deposits and the present day analogue communities suggest that some of the elements belonging to the original biocoenosis are absent. Thus the other main associated species of this habitat as small opportunistic capitellid and spionid polychaetes and isopods that are adapted to living in a highly perturbed environment, have not been fossilized. Dosinia lupinus and Donacilla cornea are also present in the otherwise impoverished fauna of this environment and confirm shallow water sandy environment (Koukouras \& Russo, 1991). This is the only articulated in situ preserved assemblage.

3. Hard bottom biota assemblage. It consists of a wide variety of skeletal organisms and characterizes a habitat that has been formed by the drowning of former beachrock beds (Cornée et al., 2006; Moissette et al., 2013). The most representative taxa of those living on rocky substrates are: Cardita calyculata, striarca lactel, Bolma rugosa, Haliotis tuberculata, Diodora graeca, Diodora gibberula. Among those associated with seaweeds are: rissoids, Jujubinus exasperatus, J. striatus, Tricolia pullus, Alvania cancellata, Bittium reticulatum, B. latreillei, Euspira catena, Neverita josephinia and Clelandella milliaris. The latter may be enclaves within the following assemblage of Posidonia oceanica meadows. The hard rock substrates are very important since they provide both biological and geological information. They provide a stable environment for living organisms and they present a relatively high biodiversity.

4. Posidonia oceanica biota assemblage. The most representative species of sea grasses highlighted by this study, are: Gibbula ardens, Alvania lineata, Tricolia pullus, Bittium reticulatum, Jujubinus striatus, and the bivalves Arca noae, Barbatia barbata, Lima inflata, Talochlamys multistriata, Venus verrucosa.

Such fossilized species in hard bottom and Posidonia oceanica environments have been studied before in Rhodes (Moissette et al. 2007, Moissette et al. 2013), but in that case they are not in situ and they are represented with the other assemblages of the littoral bottom.

The "Ervilia castanea" deposits acted as a "refuge" for the parautochthonous elements of hard bottom and relatively deeper water assemblages, due to storm events and probably quick sedimentation. 
The analysis of these four assemblages led to the reconstruction of the littoral palaeoenvironment represented in Figure 2.

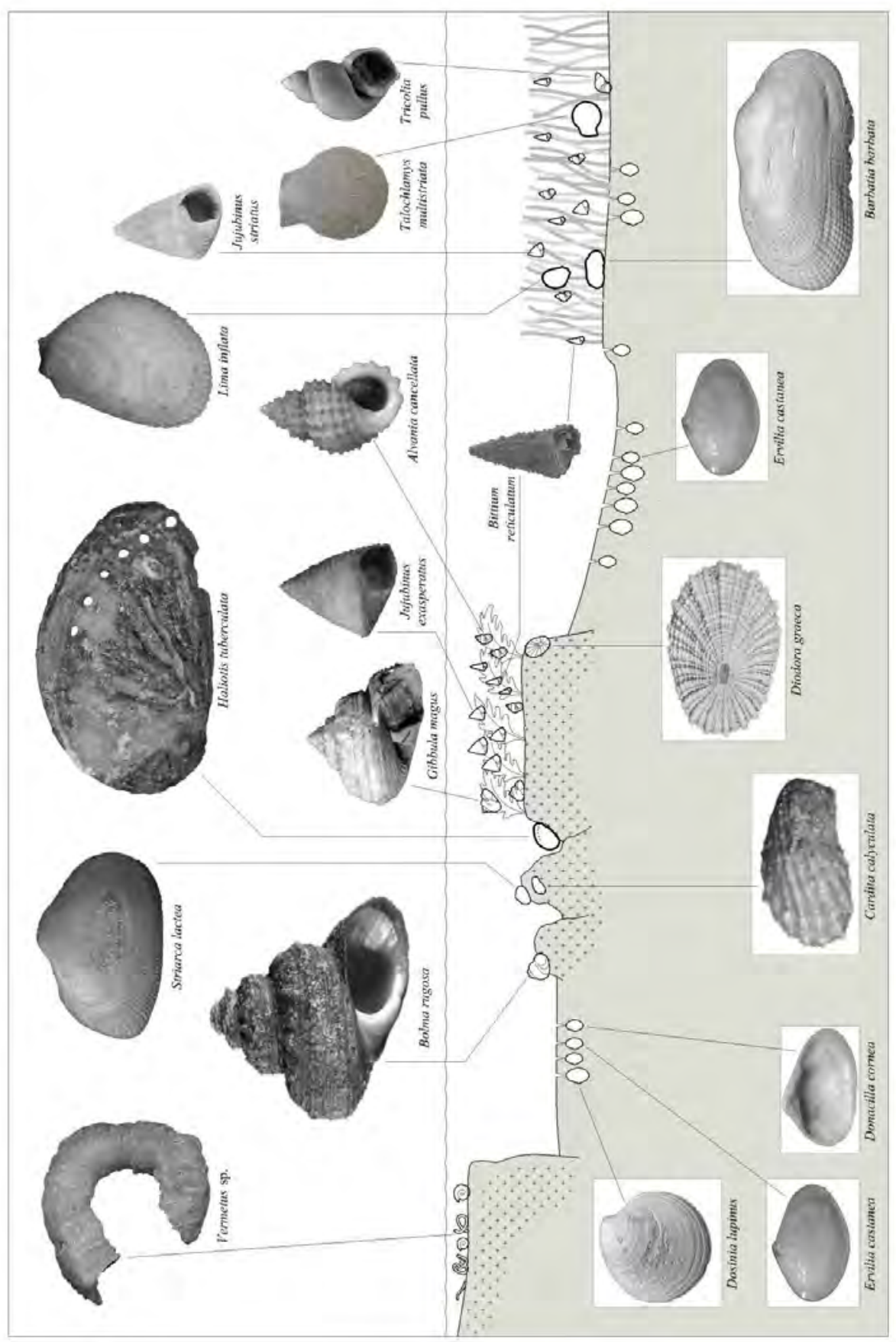

Figure 2 - Reconstruction of the sea bottom environment.

\section{Acknowledgments}

The study was carried out with the support of Pierre Moissette and Jean-Jacques Cornée and financially supported by the National and Kapodistrian University of Athens (Research Project 70/4/5849). During the preparation of drawings, Petros Patrianakkos provided great help. 


\section{References}

Barash A. and Danin Z. 1988. Marine Mollusca at Rhodes, Israel Journal of Zoology, 35, 1-74.

Barash A. and Danin, Z. 1992. Fauna Palaestina. Mollusca I. Annotated list of Mediterranean molluscs of Israel and Sinai, The Israel Academy of Sciences and Humanities, Keterpress Enterprises, Jerusalem, 405 pp.

Cornée J.J., Moissette P., Joannin S., Suc J.P., Quillévéré F., Krijgsman W., Hilgen F., Koskeridou E., Mónch P., Lécuyer C. and Desvignes P. 2006, Tectonic and climatic controls on coastal sedimentation: the Late Pliocene-Middle Pleistocene of northeastern Rhodes, Greece, Sedimentary Geology, $187 \mathrm{pp}$.

Gibbard P.L. and Head M.J. 2010. The newly-ratified definition of the Quaternary System/Period and redefinition of the Pleistocene Series/Epoch, and comparison of proposals advanced prior to formal ratification, Episodes, 33(3), 152-156.

Hanken N.-M., Bromley R.G. and Miller J. 1996. Plio-Pleistocene sedimentation in coastal grabens, north-east Rhodes, Greece, Geological Journal, 31, 271- 296.

Koukouras A. and Russo A. 1991. Midlittoral soft substratum macrofaunal assemblages in the north Aegean Sea. Pubblicazioni della Stazione Zoologica di Napoli, Marine Ecology, 12, 293-316.

Logan A. 1979. The Recent Brachiopoda of the Mediterranean Sea, Bulletin de l'Institut Océanographique, 72 (1434), 1-112.

Meulenkamp J.E., De Mulder E.F.J. and Van De Weerd A. 1972, Sedimentary history and paleogeography of the Late Cenozoic of the Island of Rhodos, Zeitschrift der Deutschen Geologischen Gesellschaft, v. 123, 541-553.

Moissette P., Koskeridou E., Cornée J-J., Guillocheau F., Lécuyer C. 2007. Spectacular preservation of seagrasses and seagrass-associated communities from the pliocene of rhodes, Greece. Palaios, 22, 200-211.

Moissette P., Koskeridou E., Cornée J-J. and André J.J. 2013. Fossil assemblages associated with submerged beachrock beds as indicators of environmental changes in terrigenous sediments: Examples from the Gelasian (Early Pleistocene) of Rhodes, Greece, Palaeogeography Palaeoclimatology and Palaeoecology, 369, 14-27.

Mutti E., Orombelli G. and Pozzi R. 1970. Geological map of Rhodes Island (Greece), Annales Géologiques des Pays Hélléniques.

Morton B. 1990. The biology and functional morphology of Ervilia castanea (Bivalvia: Tellinacea) from the Azores, Acoreana, Supplement, 75-96.

Morton B., Britton J., Martins A. 1998. Ecologia Costeira dos Acores, Sociedade Afonso Chaves, Ponta Delgada, 249 pp.

Pérès J.M. and Molinier R. 1957. Compte rendu du colloque tenu à Gênes par le comité du benthos de la Commission Internationale pour l'Exploration Scientifique de la Mer Méditerranée, Recueil des travaux de la Station marine d'Endoume, Marseille, 22(13), 5-15.

Pérès J.M. and Picard J. 1964. Nouveau manuel de bionomie benthique de la mer Méditerranée, Recueil des travaux de la Station marine d'Endoume, Marseille, 47(31), 3-137.

Pérès J.M. 1967. The Mediterranean benthos, Oceanography and Marine Biology, An Annual Review, 5, 449-533.

Pirazzoli P.A., Montaggioni L.F., Saliege J.F., Segonzac G., Thommeret Y. and VergnaudGrazzini C. 1989. Crustal block movements from Holocene shorelines: Rhodes Island (Greece), Tectonophysics, 170, 89-114.

Riedl R. 1983. Fauna und Flora des Mittelmeeres. Ein systematischer Meeresfóhrer fór Biologen und Naturfreunde, $3^{\text {rd }}$ edition, Verlag Paul Parey, Hamburg. 836 pp.

Zenetos A., Vardala-Theodorou E. and Alexandrakis C. 2005. Update of the marine Bivalvia Mollusca checklist in Greek waters, Journal of Marine Biological Association U.K., 85, 993- 998 .

Zibrowius H. 1980. Les scléractiniaires de la Méditerranée et de l'Atlantique nord-oriental, Mémoires de l'Institut océanographique, 11, 1-284. 